\title{
VACCINATION OF DOGS AND CALVES AGAINST MICROSPORUM CANIS
}

\author{
A. RYBNIKÁŘ, V. VRZAL, J. CHUMELA \\ Bioveta, Ltd., Komenského 212, 68323 Ivanovice na Hané \\ Received December 4, 1995 \\ Accepted June 6, 1996
}

\begin{abstract}
Rybnikář A., V. Vrzal, J. Chumela: Vaccination of Dogs and Calves Against Microsporum canis. Acta vet. Brno 1996, 65:161-164.

Experimental vaccine containing Microsporum canis culture showed good protective efficacy against experimental mycosis (ringworm) in challenge bioassays on dogs and calves. The efficacy of a commercial vaccine containing Trichophyton verrucosum strain proved very good against infection with $M$. canis in calves but insufficient in dogs.
\end{abstract}

Microsporum canis, Trichophyton verrucosum, vaccines, immunity

Microsporum canis Bodin 1902, a zoophilic dermatophyte, has been reported to play the main role in dermal mycotic diseases of cats and dogs (B ö h m 1981; P i nard et al. 1987; Moriello and DeBoer 1991; Sparkes et al. 1993). These carnivores are then the main source of infection for other animal species. The disease is also known to affect humans: according to S cott and Horn (1987) microsporia account for $15 \%$ of all human dermatophytoses. The development of an efficacious vaccine against $M$. canis has therefore been the objective of a number of research teams (M o s her et al. 1977; El ad and S e gal 1989; S mith et al. 1992).

The present study was designed to test the protective efficacy of a living vaccine prepared from M. canis culture in challenge bioassays on dogs and calves. Concurrent tests were made with Trichoben AV, a commercial vaccine, containing living avirulent Trichophyton verrucosum culture which has been used successfully for immunization of cattle against trichophytosis (S i e s e n o p et al. 1994). The objective was to assess its protective efficacy against experimental infection with $M$. canis (cross immunity).

\section{Materials and Methods}

The experimental animals were six-month old crosses of small-breed dogs and one-month old calves of the Bohemian pied breed. The animals of the two species were divided into the following three groups:

Group 1 animals were each vaccinated i.m. twice with prophylactic doses of Trichoben AV. a commercial vaccine containing living Trichophyton verrucosum strain TV-M-310, protective lyophilization medium and buffered saline (manufactured by Bioveta. Ltd., Ivanovice na Hané).

Group 2 animals were each vaccinated i.m. twice with experimental living vaccine prepared from Microsporum canis strain 602, protective lyophilization medium and buffered saline.

The interval between the vaccinations was 8 days in both groups.

Group 3 animals received no vaccination and served as controls.

Thirty-six days after revaccination the dogs and the calves of the three groups were each infected with challenge culture of Microsporum canis strain B-710. The challenge was carried out by the rubbing $2 \mathrm{ml}$ suspension of the culture into a $10 \times 10 \mathrm{~cm}$ area of the clipped and gently scarified skin of the right flank. The challenge dose was 2 million CFU per animal for dogs and 6 million CFU per animal for calves.

The animals were examined at intervals of several days for 32 days after challenge. At the end of the experiments skin lesions and hair specimens were collected or abrasions were made at the challenge site and examined by culture and microscopically (R y bnikář 1992). 


\section{Results}

The experimental vaccine prepared from living $M$. canis culture showed good protective efficacy (Table 1). Four out of the 5 dogs showed only negligible dermal changes at the challenge site which disappeared spontaneously after a few days. In 1 dog these changes persisted throughout the observation period. At the site of the inoculation of M. canis vaccine 3 dogs developed scales which came off after about 3 weeks.

Table 1

Test of the protective efficacy of experimental vaccine against $M$. canis and Trichoben $\mathrm{AV}$ vaccine against experimental infection with $M$. canis in dogs

\begin{tabular}{|l|l|c|c|c|c|c|c|c|}
\hline \multirow{2}{*}{$\begin{array}{l}\text { Experimental } \\
\text { group }\end{array}$} & \multirow{2}{*}{$\begin{array}{l}\text { Vaccination } \\
\text { strain }\end{array}$} & \multirow{2}{*}{$\begin{array}{l}\text { Dog } \\
\text { No. }\end{array}$} & \multicolumn{7}{|c|}{$\begin{array}{c}\text { Skin mycotic changes after challenge. } \\
\text { days after challenge }\end{array}$} \\
\cline { 4 - 9 } & & & 9 & 14 & 19 & 23 & 27 & 32 \\
\hline Vaccination & Microsporum & 7 & \pm & \pm & \pm & - & - & - \\
with & canis & 9 & + & \pm & \pm & - & - & - \\
experimental & 602 & 11 & \pm & + & + & + & + & + \\
vaccine & & 13 & \pm & \pm & - & - & - & - \\
& & 15 & \pm & \pm & - & - & - & - \\
\hline Vaccination & Trichophyton & 1 & \pm & + & + & + & + & + \\
with & verrucosum & 2 & \pm & + & + & \pm & \pm & \pm \\
Trichoben AV & TV-M-310 & 4 & + & + & ++ & ++ & ++ & ++ \\
vaccine & & 6 & \pm & + & + & ++ & ++ & ++ \\
& & 8 & \pm & + & ++ & ++ & + & + \\
\hline Non-vacci- & & 3 & \pm & + & + & + & ++ & ++ \\
nated & & 5 & - & + & + & + & + & + \\
controls & & 10 & + & + & ++ & +++ & +++ & +++ \\
& & 12 & \pm & + & ++ & ++ & ++ & ++ \\
& & 14 & + & ++ & ++ & ++ & ++ & ++ \\
\hline
\end{tabular}

- No dermal mycotic changes

\pm Minute dermal changes - scales, papullae

$+\quad$ Solitary mycotic foci

+ Mycotic foci covering more than a 1/4 of the inoculated area

+++ Mycotic foci covering more than half of the inoculated area

The efficacy of Trichoben AV vaccine in dogs was insufficient. The clinical mycotic changes observed in these dogs after challenge were almost the same as in non-vaccinated controls.

The control dogs showed hypertrophy of the skin with crusts at the challenge site. The crusts then came off revealing the hypertrophic glabrous skin. In this group the clinical mycotic changes persisted till the end of the experiment. In most of the controls the skin showed maculae violet in colour and about $0.5 \mathrm{~cm}$ in diameter from which purulent exudate flew out upon compression.

None of the calves vaccinated with either $M$. canis vaccine or Trichoben AV vaccine showed any clinical dermal mycotic changes after challenge (Table 2). The healthy skin at the challenge site became soon overgrown with new hair.

Six of the eight control calves responded to challenge by clinical changes similar to those observed in animals with experimental trichophytosis. These consisted in the development of circular foci, 1 to $2 \mathrm{~cm}$ in diameter, covered with scales or crusts which in some animals 
Table 2

Test of the protective efficacy of experimental vaccine against $M$. canis and Trichoben $\mathrm{AV}$ vaccine against experimental infection with $M$. canis in calves

\begin{tabular}{|c|c|c|c|c|c|c|c|c|}
\hline \multirow{2}{*}{$\begin{array}{l}\text { Experimental } \\
\text { group }\end{array}$} & \multirow{2}{*}{$\begin{array}{l}\text { Vaccination } \\
\text { strain }\end{array}$} & \multirow{2}{*}{$\begin{array}{l}\text { Calf } \\
\text { No. }\end{array}$} & \multicolumn{6}{|c|}{$\begin{array}{l}\text { Skin mycotic changes after challenge, } \\
\text { days after challenge }\end{array}$} \\
\hline & & & 9 & 14 & 19 & 23 & 27 & 32 \\
\hline $\begin{array}{l}\text { Vaccination } \\
\text { with } \\
\text { experimental } \\
\text { vaccine }\end{array}$ & $\begin{array}{l}\text { Microsporum } \\
\text { canis } \\
602\end{array}$ & $\begin{array}{l}5591 \\
5594 \\
5736 \\
5740 \\
5742 \\
6654 \\
6656\end{array}$ & $\begin{array}{l}- \\
- \\
- \\
- \\
- \\
-\end{array}$ & $\begin{array}{l}- \\
- \\
- \\
- \\
- \\
-\end{array}$ & $\begin{array}{l}- \\
- \\
- \\
- \\
- \\
-\end{array}$ & $\begin{array}{l}- \\
- \\
- \\
- \\
- \\
-\end{array}$ & $\begin{array}{l}- \\
- \\
- \\
- \\
- \\
-\end{array}$ & $\begin{array}{l}- \\
- \\
- \\
- \\
- \\
-\end{array}$ \\
\hline $\begin{array}{l}\text { Vaccination } \\
\text { Trichoben AV } \\
\text { vaccine }\end{array}$ & $\begin{array}{l}\text { Trichophyton } \\
\text { verrucosum } \\
\text { TV-M-310 }\end{array}$ & $\begin{array}{l}5599 \\
5600 \\
5603 \\
5739 \\
57+3 \\
57+4 \\
57+5\end{array}$ & $\begin{array}{l}- \\
- \\
- \\
- \\
- \\
- \\
-\end{array}$ & $\begin{array}{l}- \\
- \\
\pm \\
- \\
- \\
- \\
-\end{array}$ & $\begin{array}{l}- \\
- \\
- \\
- \\
- \\
-\end{array}$ & $\begin{array}{l}- \\
- \\
- \\
- \\
- \\
-\end{array}$ & $\begin{array}{l}- \\
- \\
- \\
- \\
- \\
-\end{array}$ & $\begin{array}{l}\overline{-} \\
- \\
- \\
- \\
-\end{array}$ \\
\hline $\begin{array}{l}\text { Non-vacci- } \\
\text { nated } \\
\text { controls }\end{array}$ & - & $\begin{array}{l}3725 \\
3729 \\
5612 \\
5613 \\
6672 \\
9190 \\
9192 \\
9199\end{array}$ & $\begin{array}{l}- \\
- \\
- \\
- \\
- \\
- \\
-\end{array}$ & $\begin{array}{l} \pm \\
\pm \\
\pm \\
\pm \\
\pm \\
+ \\
\pm \\
\pm\end{array}$ & $\begin{array}{c} \pm \\
+ \\
+ \\
\pm \\
+ \\
++ \\
+ \\
+\end{array}$ & $\begin{array}{c}- \\
+ \\
++ \\
\pm \\
+ \\
++ \\
+ \\
++\end{array}$ & $\begin{array}{c}- \\
+ \\
++ \\
- \\
+ \\
++ \\
+ \\
++\end{array}$ & $\begin{array}{c}- \\
+ \\
+ \\
- \\
+ \\
++ \\
+ \\
++\end{array}$ \\
\hline
\end{tabular}

For explanation of the signs,,- \pm+ and ++ see Table 1

merged into confluent crusts. In the remaining 2 control calves the challenge site showed minute superficial scales which disappeared after 9 to 13 days.

The results of examination by culture and microscopic examination in the dogs and calves at the end of the experiments were in keeping with the clinical findings: they were positive in the animals with clinical mycosis and negative in those showing no dermal changes.

\section{Discussion}

The questions of cross-immunity reactions were the subject of our previous report (R y bnikár r 1992), in which vaccination of calves with T. verrucosum strain TV-M-310 conferred very good protection against the homologous $T$. verrucosum strain as well as against $T$. mentagrophytes strain. The results reported in the present study extend the understanding of the antigenic spectrum of avirulent Trichoben AV vaccine. The producing $T$. verrucosum strain TV-M-310 ensured full protection of the calves also against experimental infection with virulent $M$. canis strain. Cross immunogenic reactivity between $M$. canis and $T$. verrucosum dermatophytes can therefore be achieved although the reverse procedure (vaccination with $M$. canis and challenge with $T$. verrucosum) failed to confer reliable immunity to calves (Rybnikár r 1993). However, the practical value of these results is only limited. Although $M$. canis-produced bovine mycoses have been reported, 
their distribution is not particularly wide (Stenwig 1985; Komárek 1989; Connole 1990).

In contrast to the experiment on calves the efficacy of Trichoben AV vaccine in dogs was insufficient. The dogs inoculated with this vaccine and challenged with $M$. canis strain developed disease of almost the same extent as non-vaccinated controls. It became apparent that an immunobiological preparation highly effective in one animal species may not produce the desired immunizing effect in another animal species although the same testing method and the same infectious agent were used in both cases.

The experimental living vaccine prepared from $M$. canis strain showed good efficacy in dogs. However, at the site of its inoculation 3 of the 5 dogs showed undesirable local scales reminiscent of mycotic foci. Although the mycological examination of these yielded negative results. possible spread of the vaccination strain in using living vaccines against canine and feline dermatophytoses cannot be excluded. This fact indicates the necessity of developing an inactivated vaccine. which became the subject of our subsequent study.

\section{Vakcinace psů a telat proti Microsporum canis}

Pokusná vakcína, obsahující živou kulturu Microsportum canis. prokázala dobrou protektivní účinnost proti experimentální mykóze v čelenžních biologických pokusech na psech a telatech. Účinnost vakcíny, obsahující vakcinační kmen Trichophyton verrucosum, proti infekci $M$. canis byla u telat velmi dobrá, u psů však nedostačující.

\section{References}

BÖHM. K. H. 1981: Dermatomykosen bei Hund und Katze. Kleintierpraxis 26:413-420

CONNOLE. M. D. 1990: Review of animal mycoses in Australia. Mycopathologia 111:133-164

ELAD. D.. SEGAL, E. 1989: Fungal ribosomal vaccines. Mycopathologia 105:49-51

KOMÁREK. J. 1989: Laboratorní diagnostika dermatofytóz zvírat v letech 1979-1988. Veterinářství 39:539

MORIELLO. K. A.. DE BOER. D. J. 1991: Fungal flora of the haircoat of cats with and without dermatophytosis. J. Med. Vet. Mycol. 29:285-292

MOSHER. C. L.. LANGENDOEN. K.. STODDARD. P. 1977: Treatment of ringworm (Microsporum canis) with inactivated fungal vaccine. Vet. Med. Small Anim. Clin. 72:1343-1345

PINARD. M., CHERMETTE, R. BUSSIERAS, S. 1987: Diagnostic et prophylaxie des teignes des carnivores domestiques. Étude critique à partir dune enquette a I Ecole nationale vétérinaire dAlfort. Rec. Méd. Vét. 163:11071116

RYBNIKÁŔ. A. 1992: Cross-immunity in calves after vaccination against trichophytosis. Acta vet. Brno 61:189194

RYBNIKÁŔ, A. 1993: Testing the protective efficacy of monovalent and bivalent antimycotic vaccines. Acta vet. Brno 62:167-172

SCOTT. D. W.. HORN, T. 1987: Zoonotic dermatoses of dogs and cats. Vet. Clin. North Am. Small Anim. Pract. 17:117-144

SIESENOP. U.. BÖHM. K. H., BRANDEBUSEMEYER, E., CONRAD, P. 1994: Untersuchungen zur Virulenz, Verträglichkeit und Wirksamkeit der Trichophytie-Lebendvakzine BIOVETA am Rind. Prakt. Tierarzt 7:605612

SMITH. J. M. B.. AHO. R.. MATTSSON. R., PIER, A. C. 1992: Progress in veterinary mycology. J. Med. Vet. Mycol. 30, Suppl. 1:307-316

SPARKES, A. H., GRUFFYDD-JONES, T. D., SHAW, S. E., WRIGHT, A. I.. STOKES, C. R. 1993: Epidemiological and diagnostic features of canine and feline dermatophytosis in the United Kingdom from 1956 to 1991. Vet Rec. 133:57-61

STENWIG. H. 1985: Isolation of dermatophytes from domestic animals in Norway. Nord. Vet. Med. 37:161-169 